INTER NATIONAL MONETARY FUND

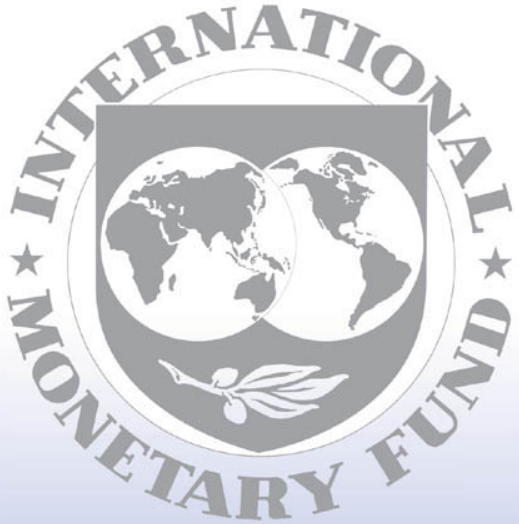

Staff

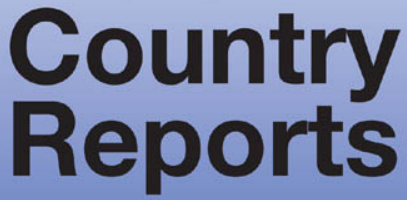




\section{Italy: Financial Sector Assessment Program- Detailed Assessment of the Observance of Monte Titoli of the CPSS/IOSCO Recommendations for Securities Settlement Systems}

This Detailed Assessment of the Observance of Monte Titoli of the CPSS/IOSCO Recommendations for Securities Settlement Systems for Italy was prepared by a staff team of the International Monetary Fund as background documentation to the Financial Sector Assessment Program with the member country. It is based on the information available at the time it was completed in February 2006. The views expressed in this document are those of the staff team and do not necessarily reflect the views of the government of Italy or the Executive Board of the IMF.

The policy of publication of staff reports and other documents by the IMF allows for the deletion of market-sensitive information.

To assist the IMF in evaluating the publication policy, reader comments are invited and may be sent by e-mail to publicationpolicy@imf.org.

Copies of this report are available to the public from International Monetary Fund • Publication Services 700 19th Street, N.W. • Washington, D.C. 20431

Telephone: (202) 6237430 • Telefax: (202) 6237201

E-mail: publications@imf.org • Internet: http://www.imf.org

Price: $\$ 15.00$ a copy

\section{International Monetary Fund}

Washington, D.C. 
This page intentionally left blank

CInternational Monetary Fund. Not for Redistribution 


\section{FinANCIAL SeCtor Assessment PROGRAM}

\section{DetaILed ASSESSMENT OF THE OBSERVANCE OF Monte Titoli OF THE CPSS/IOSCO RECOMMENDATIONS FOR SECURITIES SETTLEMENT SYSTEMS}

\section{ITALY}

FEBRUARY 2006 
Contents

CPSS/IOSCO Recommendations for Securities Settlement Systems

Tables

1. Summary of Observance of CPSS/IOSCO Recommendations $\underline{32}$

2. Actions to Improve Observance of the Recommendations..................................... 


\section{CPSS/IOSCO RECOMMENDATIONS FOR SECURITIES SETTLEMENT SYSTEMS}

\begin{tabular}{|c|c|}
\hline Recommendation 1 & $\begin{array}{l}\text { Securities settlement systems should have a well founded, clear, and transparent legal } \\
\text { basis in the relevant jurisdiction. }\end{array}$ \\
\hline Description & 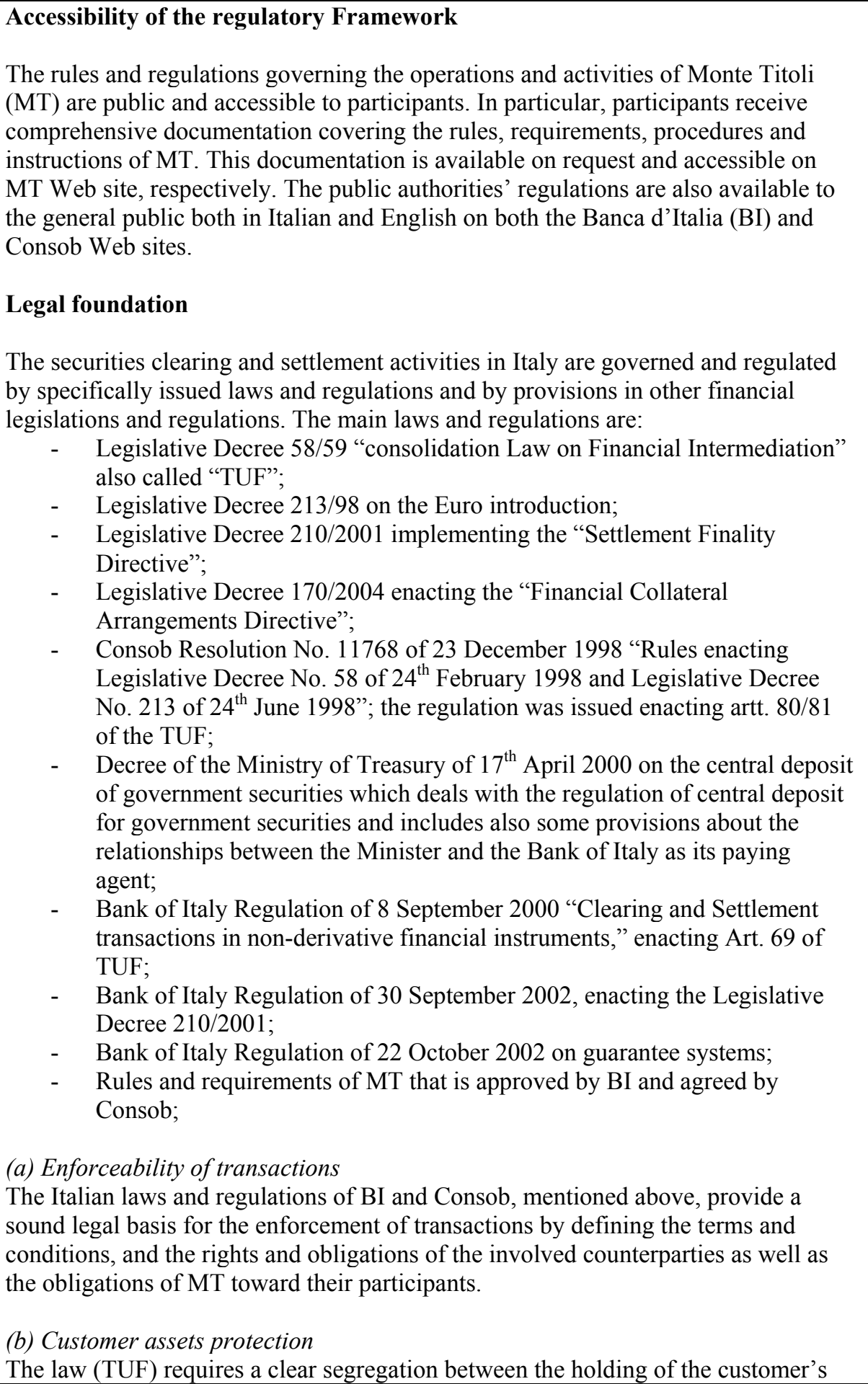 \\
\hline
\end{tabular}


assets and those of the intermediaries. At the level of the CSD, an intermediary is obliged to open an omnibus account for the securities holdings of its customers and another account for its own holdings. According to Art 39, resolution 11768, MT is also required to separate between its own securities holdings and the assets of its participants.

In addition, entities acting as custodians such as banks, investment firms and other financial intermediaries are legally obliged to have an internal accounting system that allows the identification of the holdings of their customers at any time. The procedures for the protection of customers' securities will be elaborated further under Recommendation 12.

\section{Legal Basis}

(a) Dematerialization of securities

Consob resolution no. 11768 of 23 December 1998 provides a sound and clear legal basis for dematerialized securities. The shift from physical to dematerialized securities was initiated in October 1998. Since that time, the vast majority of securities are dematerialized and transferred by book entry. For instance, all government bonds and securities traded on regulated markets are mandatory issued in a dematerialized form. This issue is discussed further under Recommendation 6.

\section{(b) Netting arrangements}

The enforceability of netting arrangement is ensured by Article 2 of the Finality Decree. Netting procedure can not be revoked in the event of insolvency procedures provided that the transfer order is given before the opening of the procedure or performed on the day of the opening. The timing of the order transfer is defined by the rules of the system and technically determined after the matching has taken place and the order has been given an individual numbering.

\section{(c) Securities lending arrangements}

Securities lending for the facilitation of settlement of the transactions at the level of the systems is regulated by the rules of MT for centralized securities lending.

In addition, the Master Securities Lending Agreement signed by the participants provide legal basis for securities lending. Moreover, the Legislative Decree $170 / 2004$ on collateral provides rules governing collateralization procedures that include issues related to securities lending.

\section{(d) Finality of settlement}

The legal validity of settlement finality is enforced by the TUF Art. 71, which ensured finality of both payment and securities transfers performed through designated systems. In particular, the provisions ensure the irrevocability, finality and protection against third party claims.

\section{(e) Delivery versus payment (DVP)}

The Italian legal framework requires MT to comply with the DVP principle. In fact Art. 9, par.4 of the Clearing and Settlement Regulations establishes that "the management company shall adopt all the necessary measures to ensure that settlement of financial instruments is irrevocable and simultaneous with settlement of the cash leg." 
DVP. In particular, it states that the transfer of cash and securities is conditional upon each other and simultaneous, and, thereby, this requirement eliminates the principal risk. Furthermore, the rules of MT provide certainty for DVP, as the transfer of securities is conditional upon cash being available at the participant account at the central bank.

\section{Challenges by a court}

No court case has yet occurred.

\section{Enforceability of rules and regulations in the event of a bankruptcy}

The enforceability of transactions settled within a designated system is governed by Art 2 of the Finality Decree which provides protection to the validity of the transaction and against any third party claim.

\section{Cross-border participation}

MT has participants from the European Economic Area (EEA), Switzerland and United States. The link established between MT and foreign participants, in particular, foreign CSDs are free of payment links. The level of activities is relatively moderate.

\section{Conflict of law issues}

For participants from the EEA, a careful analysis of the relevant legislative framework has been done at several levels. For instance, for its monetary policy operations, the ECB has carried out a thorough assessment of the links established by MT, where the provision of legal opinions was a condition for the eligibility of the link. For market operations, the European Central Securities Depositories Association (ECSDA) has carried out several analyses on the legal implication of establishing links within the European Union.

For foreign CSD, MT requested legal analyses on the relevant jurisdictions including the provision of legal opinions. MT is currently analyzing these legal opinions. 
Comments
According to a major market participant, it is not entirely clear in the Italian legislation whether the ownership transfer, particularly for OTC transactions, occurs at the time of trade execution or at the time of settlement. According to the self assessment, the Italian public authorities stated that "the transfer of title on rights arising from securities is assigned by the registration in the intermediaries' accounts." This wording may create an ambiguity for market participants with regard to the timing of the ownership transfer. Nevertheless, this issue would not have an impact on insolvency procedures, as according to the Art.2, par.1 of the Finality Decree, transfer orders entered into a designated system are enforceable notwithstanding the insolvency of a participant.

The ambiguity on the timing of ownership transfer may have some financial and taxation impacts for the intermediaries and their customers, as it creates uncertainty with regard to the receiver of the outcome of corporate events and who is subject to tax payment.

The authorities considered that there cannot be any uncertainty about the moment from which the buyer is entitled to exercise property rights. The Euro Decree (n. 213/98) and the Consolidated Law on Finance (n. 58/98) state that the legitimate exercise of all the rights relating to the securities being transferred (title to participate in the shareholders' meeting, corporate actions, etc.) is strictly linked to the registration in the intermediaries' accounts. Moreover the enforceability, certainty, finality of transactions entered in the SSS are clearly disciplined by laws and rules governing the functioning of the SSS, from the moment of entry into the system to that of exit, even in case of settlement failures. According to the art. 2 of the Legislative Decree n. 210/2001, no action, including that of nullity, may prejudice the finality of transfer orders, their netting and the consequent payments and transfers with respect to the system.

Nevertheless, the authorities indicated that the "transfer of ownership" issue was extensively discussed by the "Express User Group" in its meeting on February 16 2005 and the Authorities made it clear that they stand ready to revise the regulation within their competence in order to better clarify the point, if the market deems it necessary or even desirable. However, according to the authorities, no clear consensus on the need to intervene emerged in that occasion or following months.

In January 2005, the EU Commission set up the Legal Certainty Group which, inter alia, will advise the Commission on how to harmonize the "timing" of transfer of ownership at a European level.

Confirmation of trades between market participants should occur as soon as possible after trade execution, but no later than trade date $(\mathrm{T}+0)$. Where confirmation of trades by indirect market participants (such as institutional investors) is required, it should occur as soon as possible after trade execution, preferably on $\mathrm{T}+0$, but no later than $\mathrm{T}+1$.

\section{Trade matching of settlement instruction}

For transactions traded on regulated markets, trade confirmation and matching is required prior to the settlement.

All transactions settled by Express II are automatically confirmed and matched by the Riscontro e Rettifica Gionalieri (RRG), which guarantees the correspondence of information related to the specifications of the transaction. The RRG is 
electronically connected to the trading system with automated procedures. This straight trough processing implies that 100 percent of trade confirmation between direct participants is achieved on $\mathrm{T}+0$ for transactions traded on regulated markets.

For OTC transaction, 90 percent of trade is confirmed on $\mathrm{T}+0$.

\section{Confirmation procedure for indirect participants}

The RRG system provides the possibility to confirm the trade between the direct participant and the indirect participant as long as the positions of the latter are settled in Express II. In this case, the RRG allows trade confirmation for indirect participants to take place on $\mathrm{T}+0$.

\begin{tabular}{|l|}
\hline Assessment \\
\hline Comments \\
\hline Recommendation 3
\end{tabular}

Observed

Recommendation 3

Rolling settlement should be adopted in all securities markets. Final settlement should occur no later than $\mathrm{T}+3$. The benefits and costs of a settlement cycle shorter than $\mathrm{T}+3$ should be evaluated.

\section{Settlement Cycles}

Trade transactions are settled on a rolling basis in the regulated market. The settlement cycles are as follows:

- Transaction for monetary policy operations: $\mathrm{T}+0$

- MTS repo transactions: overnight $\mathrm{T}+0$, spot next, $\mathrm{T}+2$, corporate $\mathrm{T}+3$

- Short term government securities: $\mathrm{T}+2$

- Equities: $\mathrm{T}+3$.

- OTC trades: negotiable between the involved counterparties, but the majority of these transactions are settled on $\mathrm{T}+0$.

\section{Settlement failures}

Since the start of operation of Express II on 8 December 2003, with the exception of the first week of operation, the number of failed settlements was very small and did not exceeded 0.2 percent of total settlement.

\section{Incentive to settle on the contractual date}

The rules and requirements of MT define, in agreement with BI and Consob, penalties in order to discourage participants from not fulfilling their settlement obligations on due time. However, due to the low level of failed settlement, penalties have never been used.

The settlement statistics are published on MT Web sites.

In order to reduce the number of failed transactions, the following measures are in place:

- an automated securities lending facility;

- an automated collateralization mechanism for eligible counterparty;

- three steps settlement procedures with time lag that provides opportunities for counterparties to cover their securities or cash shortage: overnight net settlement, daylight net settlement and RTGS mechanism;

- availability of CCP. 


\section{Cost benefit analysis of enrolling and shorter settlement cycle}

The settlement of transactions is based on a rolling basis.

The shortening of the settlement cycles in Italy is only relevant for OTC market, and possible shortening of the settlement cycle for equities less than $\mathrm{T}+3$.

As far as the OTC market, the nature of the market does in fact allow market participants to negotiate the date of settlement. The Italian authority can, in this case, encourage but not force market participants to agree on a shorter settlement date.

With regard to equities settlement, the Italian authority is involved in discussion at the European level on whether there is a need to shorten and harmonize the settlement cycles for the entire EU. The ESCB-CESR agrees to initiate, in cooperation with market participants, to carry out a cost benefit analysis on a shorter and harmonized settlement cycle for the European market.

\begin{tabular}{|l|}
\hline Assessment \\
\hline Comments \\
\hline Recommendation $\mathbf{4}$
\end{tabular}

Description

Observed

The benefits and costs of a CCP should be evaluated. Where such a mechanism is introduced, the CCP should rigorously control the risks it assumes.

\section{The activities of the CCP}

The activities of CCP in Italy are carried out by $C C \& G$ which was established in August 1992. It started its operations by managing a guarantee fund for the equities market and acting as a $\mathrm{CCP}$ on interest rates futures. Its activities have recently expanded to cover derivatives linked to the equities market (futures and options), Nuovo Mercato, convertible bonds, warrants, units of closed-end funds and ETFs with the exception of stocks undergoing an OPA (public purchase offer/take-overbid offer). CC\&G, moreover, manages a guarantee mutual fund for the TLX market.

CC\&G, in cooperation with Clearnet (French CCP), provides jointly CCP services on optional basis for trades on the MTS markets (government bonds, cash and repo), thus realizing the model of a virtual single $\mathrm{CCP}$ for cross-border clearing. $\mathrm{CC} \& \mathrm{G}$ and Clearnet are linked to each other as general clearing members that allow dealers to trade with intermediaries belonging to one or the other CCP. For the smooth functioning of the virtual CCP, CC\&G and Clearnet have harmonized their pricing structures, methods for calculating margins and capital requirements for membership. Six foreign intermediaries participating by remote access signed up with the central counterparty service at its inception. By the end of the first quarter of 2003 their number had increased to nine.

\section{Netting arrangements}

The netting arrangements are carried out by open offer. CC\&G interposes itself between clearing members at the time trades are executed. The netting arrangement is protected and enforced by a sound legal framework, i.e., article 2.1 of the Finality Decree, and subsequent regulations issued by BI in agreement with the Consob (see Recommendation 1). The CC\&G was notified to the European Commission as a designated system as of 2001.

Financial and operational standards for participation 
CC\&G has comprehensive rules to ensure compliance with standards of a financial, organizational and technical nature to participants admitted to the system as clearing members. In addition to strict membership requirements, counterparty risk is managed through a system of margins requirement (both initial margin and supplementary margin). Margins are calculated and collected on a daily basis. Furthermore, positions are recalculated on an intra-day basis in order to ensure the adequacy of the margins' amounts. In addition, $C C \& G$ established two default funds (one for the equity market and the other for the MTS markets). Cash margins and contribution to the clearing funds are settled in central bank money.

\section{Liquidity risk management}

CC\&G manages its liquidity risk by:

1. preliminary netting all payments be made/received to/from any participant;

2. requiring that clearing members in debit position pay by 9:30 a.m.; only then are payments to clearing members in credit position made.

3. notifying the request for additional margin in good time when additional intraday margins are needed.

4. having access to committed credit lines by leading Italian commercial banks (collateralized and not collateralized cash lines). As regards securities, CC\&G avails itself of the securities lending facilities offered by leading Italian banks, with which contractual agreements have been signed.

\section{Measures to withstand default}

The default fund for derivatives and equities covers risks relating to participants' multiple default of the three largest participants.

With regard to the MTS market, on which the CC\&G has recently started its operations, $C C \& G$ will review the current amount of the dedicated default fund on the basis of the level of activity and participation.

Since the start of its operation, $C C \& G$ has not experienced default of general clearing members. However, there have been cases of default of nonclearing members handled by the concerned general member in accordance with B.6.2.2. of the CC\&G Rules.

\section{Financial resources}

$\mathrm{CC} \& \mathrm{G}$ relies on the following resources:

- the margin system;

- $\quad$ the default fund (determined on the basis of a stress test scenario);

- committed credit lines;

- own financial resources.

The adequacy of the financial resources is periodically assessed by the Risk Committee following structured stress tests run by the Risk Management Department. Margins and funds are segregated by destination, in compliance with the TUF and may not be used for other purposes or be subject to enforcement procedures.

\section{Transparency of loss allocation rules}

The coverage of losses (or default) of the participants takes place in accordance with the rules established by the CC\&G, available in Italian and in English on the CC\&G 


\begin{tabular}{|c|c|}
\hline & Web site. \\
\hline Assessment & Observed \\
\hline Comments & $\begin{array}{l}\text { The CC\&G is considered compliant with the current wording of Recommendation } 4 \text {, } \\
\text { which mainly deals with the cost benefit of introducing a CCP. The newly issued } \\
\text { CPSS/IOSCO Recommendations for CCP cover broader aspects such as risk } \\
\text { management and supersede the recommendations for SSS. For this reason, the } \\
\text { Italian public authorities may consider to assess CC\&G against the new } \\
\text { CPSS/IOSCO Recommendations for CCP. }\end{array}$ \\
\hline Recommendation 5 & $\begin{array}{l}\text { Securities lending and borrowing (or repurchase agreements and other economically } \\
\text { equivalent transactions) should be encouraged as a method for expediting the } \\
\text { settlement of securities transactions. Barriers that inhibit the practice of lending } \\
\text { securities for this purpose should be removed. }\end{array}$ \\
\hline Description & $\begin{array}{l}\text { Institutional arrangement } \\
\text { Securities lending operations in Italy are supported by comprehensive legislative and } \\
\text { regulatory frameworks, and accounting and tax systems. In particular, securities } \\
\text { lending is subject to the general rules on lending agreements provided by the Italian } \\
\text { Civil Code (such as Art. } 1813 \text { on loan agreements and Art. } 1548 \text { on repurchase } \\
\text { agreements). Recently, the legal underpinnings for securities lending activity have } \\
\text { been enhanced through the implementation of the Legislative Decree on Collateral. } \\
\text { From a fiscal standpoint the securities lending activity is clearly supported by the tax } \\
\text { code (Dpr n.917 of 1986, modified by d.lgs. n. } 344 \text { of 2003). } \\
\text { Securities lending facilities } \\
\text { The well developed repo market in Italy allows market participants to easy access to } \\
\text { securities borrowing. Securities lending activity is also carried out by intermediaries, } \\
\text { on a bilateral basis. } \\
\text { MT has recently established a centralized securities lending facility to support the } \\
\text { settlement process during both the overnight netting and the daylight netting } \\
\text { batches. During both batches, the securities lending service is activated in case of a } \\
\text { securities shortage. The service generates automated requests that are added to the } \\
\text { transactions to be settled at the end of the respective batches. There are no } \\
\text { restrictions on the range of securities or participants in the securities lending service } \\
\text { provided by MT but some securities may be excluded from the service: (i) some } \\
\text { bonds with anticipated maturity date (or maturing during or at the end of the } \\
\text { lending period); (ii) other securities identified by the Markets. MT acts as an agent, } \\
\text { which means that it does not assume the principal risk. It is the securities lenders } \\
\text { who assume the credit risk. } \\
\text { Review of management procedures by supervisors and overseers } \\
\text { The securities lending facility provided by MT is subject to the rules and regulations } \\
\text { governing the settlement activities and supervised by BI and Consob. Article } 10 \text { of } \\
\text { the Clearing and Settlement Regulations states that the settlement services } \\
\text { management company may perform the securities lending activity for the purpose of } \\
\text { expediting settlement process. } \\
\text { MT provides some risk management tools to participants: one of the risk }\end{array}$ \\
\hline
\end{tabular}




\begin{tabular}{|c|c|}
\hline & $\begin{array}{l}\text { management measures for securities lending is the provision of a "White List" both } \\
\text { for borrower and for lender. This function enables both parties to manage the list of } \\
\text { all counterparties to which they are willing to lend or from which they may request a } \\
\text { loan. } \\
\text { The MTS repo market is subject to BI's regulation and supervision. } \\
\text { The bilateral lending between participants is subject to the general prudential } \\
\text { supervision. }\end{array}$ \\
\hline Assessment & Observed \\
\hline Comments & $\begin{array}{l}\text { MT's securities lending facility, which was developed recently, has not yet been } \\
\text { used to a significant extent. In this context, some market participants noted the lack } \\
\text { of standardized documentation. While MT is currently working developing the } \\
\text { required legal documentation, it is recommended that MT accelerate the work to } \\
\text { reduce legal uncertainty. } \\
\text { According to the authorities, MT consulted its participants on the improvement of } \\
\text { the securities lending service; as the summary of responses reports "participants } \\
\text { highlighted in their responses that this topic was not considered a high priority in } \\
\text { relation to other items included in the consultation. Although most respondents } \\
\text { agreed that the availability of a cost effective, efficient securities lending platform } \\
\text { is of benefit to all participants, some of them indicated that any such facility } \\
\text { provided by MT should be considered supportive of, rather than competing with, } \\
\text { commercial lending facilities offered in the marketplace." } \\
\text { MT, however, committed to propose some enhancements, both on the legal and } \\
\text { operational grounds, in order to promote the use of the service. }\end{array}$ \\
\hline Recommendation 6 & $\begin{array}{l}\text { Securities should be immobilized or dematerialized and transferred by book entry } \\
\text { in CSDs to the greatest extent possible. }\end{array}$ \\
\hline Description & $\begin{array}{l}\text { Dematerialization } \\
\text { Since the Legislative Degree No. } 213 \text { of } 24 \text { June } 1998 \text { on dematerialization came } \\
\text { into force in 1998, almost all securities in Italy have been issued in dematerialized } \\
\text { form. According to this law, dematerialization is mandatory for: } \\
\text { - all securities traded in regulated markets; } \\
\text { - all securities meeting certain requirements stated by Consob, such as high } \\
\text { degree of circulation; } \\
\text { - all Government bonds. } \\
\text { Companies for which the process is not compulsory have also taken advantage of } \\
\text { the opportunity to dematerialize their securities issuance. } \\
\text { For the very few issues which are not dematerialized, securities are mainly } \\
\text { represented by jumbo or global certificates which are immobilized at MT and } \\
\text { transferred electronically by book entries without any physical transfer. } \\
\text { About } 99.9 \text { percent of the securities held by MT are issued on a dematerialized } \\
\text { basis. The remaining } 0.1 \text { percent is issued as a physical certificate. } \\
\text { Transfer of title }\end{array}$ \\
\hline
\end{tabular}




\begin{tabular}{|c|c|}
\hline & $\begin{array}{l}\text { MT operates an indirect account holding system. According to Legislative Decree } \\
\text { No. 213, the transfer of title on rights arising from securities is assigned by the } \\
\text { registration in the intermediaries' accounts rather than by the registration in the } \\
\text { issuers' official register. In particular, according to Art. } 41 \text { of Consob Regulation } \\
\text { No. } 11768 \text {, at the end of the securities settlement process, or subsequent to transfers } \\
\text { ordered by intermediaries, MT notifies by electronic message the intermediaries that } \\
\text { the transfer has been registered in the relevant accounts held by MT. As soon as the } \\
\text { intermediaries receive this notification, intermediaries shall make the necessary } \\
\text { entries in their accounts. } \\
\text { The registration in the shareholders' register kept by the issuers assigns to the } \\
\text { persons recorded in this official book shareholders and patrimonial rights. } \\
\text { According to Italian law (Art. } 89 \text { of TUF), intermediaries shall only send to issuers } \\
\text { the names of persons who have requested the certification granting them the right to } \\
\text { vote at the Shareholders' Meeting, of those to whom dividends have been paid and } \\
\text { of those who have exercised pre-emption rights, specifying the quantities of shares } \\
\text { in question. The reports must be made within three days of the aforementioned } \\
\text { events. The registration in the shareholders register could be made by issuers also } \\
\text { on request of the shareholders. }\end{array}$ \\
\hline Assessment & Observed \\
\hline Comments & \\
\hline Recommendation 7 & $\begin{array}{l}\text { CSDs should eliminate principal risk by linking securities transfers to funds transfers } \\
\text { in a way that achieves delivery versus payment. }\end{array}$ \\
\hline Description & $\begin{array}{l}\text { Institutional framework for DVP } \\
\text { The Express II system, operated by MT, is based on two DVP modalities: Real Time } \\
\text { Gross Settlement, and Net Settlement, where both the cash and securities are netted. } \\
\text { Both RTGS and Net Settlement functionalities are based on DVP mechanism, where } \\
\text { the settlement of the cash and securities is executed simultaneously. The settlement } \\
\text { of securities takes place by book-entry on the securities accounts held by } \\
\text { participants at MT and the settlement of cash is carried out in central bank money } \\
\text { through a real time link to the BI-REL system (RTGS Payment system) operated by } \\
\text { BI. } \\
\text { Express II has two net settlement batches; an overnight batch between } 21.00 \text { on S-1 } \\
\text { and 7:00 on S, and a daylight batch between 9:30 and 13:00 on S. The RTGS system } \\
\text { is running between 7:00 and 18:00 on each business day. } \\
\text { Net settlement batch } \\
\text { This net settlement process is activated only on the basis of the availability of cash } \\
\text { and securities. The assets will be reserved by moving them to a technical account, } \\
\text { unavailable for the participants, and then the netting batch will be activated. If there } \\
\text { are not enough assets the transaction will be excluded from the net settlement batch. } \\
\text { This netting model differs from the classical multilateral netting model, described by } \\
\text { the BIS, as the netting batch is initiated only if the assets are available and blocked. } \\
\text { In the classical model, the batch is initiated before the checking takes place and } \\
\text { participants are exposed to counterparty risk as securities and/or cash may not be } \\
\text { available during the settlement process. }\end{array}$ \\
\hline
\end{tabular}


After the result of the continuous net matching is achieved, the system starts the optimization process based on an algorithm that identifies the maximum amount of transactions that can be settled taking into account the availability of the securities and cash (including, liquidity reserve + proceeds of collateralization + reimbursement of government securities). Information on the availability of the cash is provided by BI before BIREL is closed. Having established the availability of the securities and cash, the multilateral netting is initiated and the securities are transferred to a technical securities account. As a consequence, securities are, at this stage, unavailable to the delivering participants. Transactions that are not covered by the securities or cash are set aside and sent to the subsequent daylight net settlement; and if there is still a shortage of securities and/or cash the transactions will be forwarded to the RTGS component.

\section{RTGS settlement}

The RTGS system settles what is left from the net batches as well as any transactions submitted to the systems by participants. The RTGS system processes the transactions according to the following procedures:

a) it checks the availability of the seller's securities account and, if the outcome is positive, places an accounting block equal to the negotiated quantity, until receiving notification that the cash settlement from BIREL is completed;

b) if the seller's securities account has insufficient availability, the transaction is conveyed to the queue-management system.

c) If there is insufficient availability in the account with BI, the transaction is routed to the BIREL stand-by lists. If the transaction is cancelled from BIREL system's stand-by lists, the RTGS system deletes the transaction and removes the block previously put on the seller's securities account.

Immediately after receipt of the positive outcome of cash settlement, gross settlement:

a) removes the block placed on the seller's securities account;

b) executes securities settlement, debiting the seller and crediting the buyer for the quantity involved in the transaction.

The net and gross settlement Service Manuals are available on Monte Titoli's Web site.

The percentage of trades settled by MT on a DVP basis, where cash is involved, is 100 percent. Of total transactions settled by MT, 5 percent are settled, at the initiative of participants, on a free of payment (FOP) basis. These transactions are mainly for OTC activities, collateralization and cross-border activities.

\begin{tabular}{l|l} 
Assessment & Orments \\
\hline Recommendation 8 & F
\end{tabular}

Description

Observed

Final settlement should occur no later than the end of the settlement day. Intraday or real-time finality should be provided where necessary to reduce risks.

Timing of settlement finality

MT provides real time finality and intraday finality. In fact, the RTGS allows real time finality after the execution of DVP settlement. For the overnight batch, finality is achieved at 7:00 a.m. and for the daylight batch at 1.00 p.m. For transactions 
received after this time and when there is a need for the same day delivery, settlement is carried out by the RTGS system.

Monetary policy operations are settled by the RTGS system and finality is achieved trough out the day on a real time basis.

All settlement and book-entry transfer procedures offer real-time or intra-day finality. The intra-day and real time finality are at the complete disposal of each participant and can be used by both trading parties and the CCP in order to manage their risks efficiently or to facilitate the smooth functioning of markets.

Transactions sent through cross-border links are settled in real time and finality is achieved immediately.

\section{Revocation of unsettled transaction}

Once a transfer instruction has been matched, it is not possible to revoke it (both bilateral and unilateral requests) even if it is unsettled.

\begin{tabular}{|c|c|}
\hline Assessment & Observed \\
\hline Comments & $\begin{array}{l}\text { It is recommended that MT, in agreement with the BI and Consob and after } \\
\text { consulting market participants, may reconsider the possibility to allow } \\
\text { counterparties to revoke matched instructions when it is requested by both } \\
\text { counterparties. This would provide some flexibility to the counterparties to } \\
\text { postpone the settlement of specific transactions to a later date. In almost all } \\
\text { European systems, matched instructions can be revoked if both counterparties agree } \\
\text { upon it. } \\
\text { According to the Authorities, Italian post-trading infrastructure counterparts are de } \\
\text { facto allowed to revoke matched instructions, if both of them agree; from an } \\
\text { operational point of view such a result is possible by way of entering into the } \\
\text { system an additional instruction, equal to the original one but of opposite sign. }\end{array}$ \\
\hline Recommendation 9 & $\begin{array}{l}\text { CSDs that extend intraday credit to participants, including CSDs that operate net } \\
\text { settlement systems, should institute risk controls that, at a minimum, ensure timely } \\
\text { settlement in the event that the participant with the largest payment obligation is } \\
\text { unable to settle. The most reliable set of controls is a combination of collateral } \\
\text { requirements and limits. }\end{array}$ \\
\hline Description & $\begin{array}{l}\text { Measures to handle failure } \\
\text { The Express II RTGS facility is a real time settlement process where trade for trade } \\
\text { is settled with immediate finality. In the event that the participant does not have the } \\
\text { securities or the cash the settlement will not take place unless the participant is } \\
\text { eligible for securities lending and/or intraday credit from BI. As mentioned under } \\
\text { Recommendation 5, MT operates securities lending facility as an agent. } \\
\text { Furthermore, it has an electronic link to the cash transfer system of the central bank, } \\
\text { refer to Recommendation } 7 \text {. To receive credit from BI, the participants need to } \\
\text { provide collateral for the beneficiary of BI. The collateralization mechanism is } \\
\text { automated and managed by MT. } \\
\text { In line with TARGET rules, investment firms are also allowed to get intraday credit } \\
\text { from BI to settle their transactions. Since investment firms are not eligible for }\end{array}$ \\
\hline
\end{tabular}


monetary policy operations, they have either to provide guarantee by a credit institution or receive credits under special requirements. Fur further details, see Recommendation 10.

The Express II net settlement batches are designed to avoid settlement failures. As mentioned in Recommendation 7 on DVP, the netting process will be activated only on the basis of the availability of securities and cash. In the event that the participant does not have enough securities or cash, and is not eligible for securities lending or intraday liquidity, the transaction will be excluded form the netting batch and forwarded to the real time gross settlement procedure in order to attempt their settlement. The transactions will be maintained in the system for settlement for a period decided by the rules of the CCP which can be up to 7 days. For OTC transactions, the period of time is agreed by the two counterparties. The use of CCP is mandatory for the equity transactions carried out on the Borsa Italiana markets (i.e., equities, warrants and convertible bonds).

\section{Overdraft or debit balances}

Overdrafts or debit balances in securities are strictly forbidden by MT. It is technically not feasible due to the accounting structure of MT that is based on double accounting and the sum of securities booked on the accounts of the participants has to equal the holding booked in the issuer accounts at any time.

\section{Assessment of multiple failure}

The procedure of Express II identifies the optimal subset of transactions to be settled on the basis of available cash and securities and in accordance with the priority criteria set forth in the "Operational Rules." To this purpose, the procedure uses an algorithm mechanism, designed to ensure settlement. Extensive stress tests of the algorithm, both in terms of number and value of transactions, were carried out in October 2003 when multiple failure scenarios were tested. These tests enabled MT to carry out fine-tuning adjustments to the optimization algorithm in order to reduce the number of fails to the present low level. Furthermore, the mandatory use of CCP for the equity transactions carried out on the Borsa Italiana markets eliminates counterparty risk.

\begin{tabular}{|l|l|}
\hline Assessment & $\begin{array}{l}\text { Observed } \\
\text { Not applicable for Express II RTGS facility }\end{array}$ \\
$\begin{array}{l}\text { The assessment and rating of this recommendation are based on the written } \\
\text { information provided by the authorities that the net settlement batch will only cover } \\
\text { transactions where the securities and cash are available and have been blocked for } \\
\text { the purpose of the settlement. This model is quite different from the classical } \\
\text { netting settlement system, where the batch is initiated before the check of the } \\
\text { availability of securities and cash is carried out. This classical netting model suffers } \\
\text { from some shortcomings such as exposing the participants to implicit credit risk. } \\
\text { According to the information received from the authority on the functionality of } \\
\text { MT's net settlement system, this risk will not materialize in the case of MT. } \\
\text { However, the level of end-of-day failure remains slightly higher in terms of value } \\
\text { of transactions (about 1.2\%), while it is low in terms of volume (about 0.35). In } \\
\text { order to reduce settlement failures to insignificant level in terms of value, MT may } \\
\text { consider to strengthen its stress testing by analyzing various scenarios for the } \\
\text { uncovered cash positions and further fine-tuning adjustment of the optimization }\end{array}$ \\
\hline
\end{tabular}




\begin{tabular}{|c|c|}
\hline & algorithm. \\
\hline Recommendation 10 & $\begin{array}{l}\text { Assets used to settle the ultimate payment obligations arising from securities } \\
\text { transactions should carry little or no credit risk. If central bank money is not used, } \\
\text { steps must be taken to protect CSD members from potential losses and liquidity } \\
\text { pressures arising from the failure of the cash settlement agent whose assets are used } \\
\text { for that purpose. }\end{array}$ \\
\hline Description & 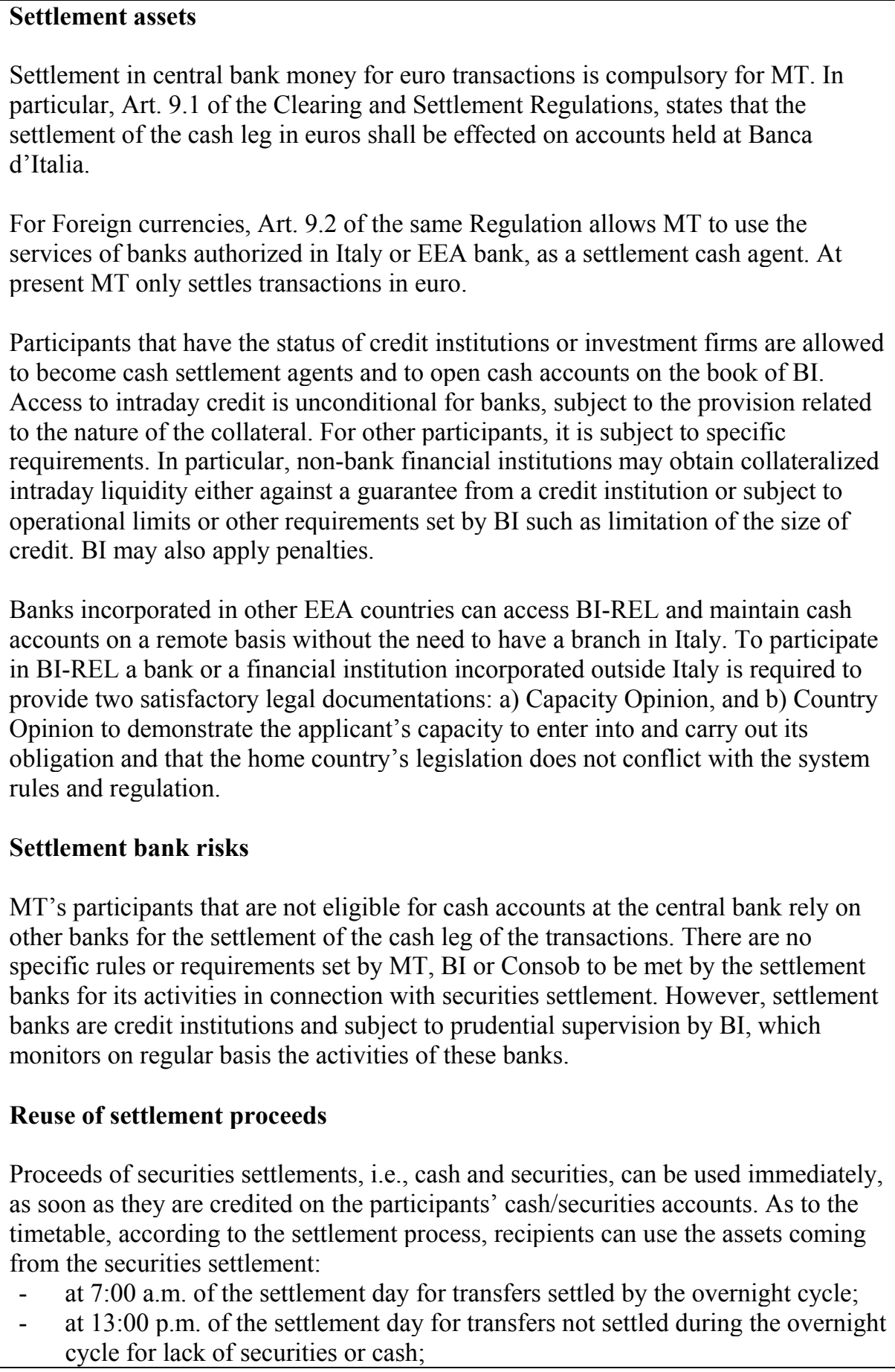 \\
\hline
\end{tabular}




\begin{tabular}{|c|c|}
\hline & - $\quad$ in real time for transactions settled by the RTGS system. \\
\hline Assessment & Observed \\
\hline Comments & $\begin{array}{l}\text { In order to monitor and limit the magnitude of the risk assumed by settlement banks } \\
\text { in connection with settlement activities, it is important that co-ordination exists } \\
\text { between the staff of BI responsible for oversight of settlement systems and those } \\
\text { responsible for banking prudential rules. } \\
\text { According to the authority, the coordination among the different supervisory } \\
\text { responsibilities of the Banca d'Italia is ensured at any level: } \\
\text { - the organizational structure of the Bank provides a high level committee (so- } \\
\text { called interfunctional committee) which gathers the top managers of all the areas } \\
\text { dealing with supervisory matters: Central Bank and Markets, Banking and } \\
\text { Financial Supervision, Payment Systems. The Committee meets periodically and } \\
\text { discusses issues of common interest; } \\
\text { - statistical data are mutually available among supervisory functions; } \\
\text { - an internal agreement has been signed among the three above-mentioned areas, } \\
\text { with a view to making it clear "who does what" in stress circumstances and } \\
\text { avoiding the spill-over of the risk arising from the disruption of a settlement } \\
\text { agent. This agreement regulates, inter alia, the exchange of information in the } \\
\text { case of opening of an insolvency proceedings of an intermediary supervised by } \\
\text { the BI; the Banking and Financial Supervision area forwards such information to } \\
\text { the Payment Systems and Central Bank and Markets areas a few days before the } \\
\text { opening of the proceedings in order to identify timely which designated systems } \\
\text { the intermediary participates in. Pursuant to the "Finality decree," the BI } \\
\text { immediately notifies Consob, the Italian designated systems, the ECB and the } \\
\text { competent authorities of the other EU member States of the opening in Italy of } \\
\text { insolvency proceedings against a financial intermediary. }\end{array}$ \\
\hline Recommendation 11 & $\begin{array}{l}\text { Sources of operational risk arising in the clearing and settlement process should be } \\
\text { identified and minimized through the development of appropriate systems, controls } \\
\text { and procedures. Systems should be reliable and secure and have adequate, scalable } \\
\text { capacity. Contingency plans and backup facilities should be established to allow for } \\
\text { timely recovery of operations and completion of the settlement process. }\end{array}$ \\
\hline Description & $\begin{array}{l}\text { Procedures for identifying and managing operational risks } \\
\text { The responsibility for identifying and managing operational risks of MT is assumed } \\
\text { by the companies' senior management, taking into account the recommendations of } \\
\text { the auditors (Internal Auditing, External Auditors and Statutory Auditors). Risk } \\
\text { management policies are then established and periodically reviewed. They are } \\
\text { formalized in the companies' official documentation. MT has a Risk Map which } \\
\text { identifies all the risks relating to its activities as well as the accountability for } \\
\text { managing and monitoring risks. The operational risk is monitored and managed } \\
\text { through the following processes/tools: } \\
\text { - The system of internal controls (manual and automated controls, insurances, } \\
\text { organizational measures, etc.) and the supervision and monitoring of } \\
\text { compliance are entrusted to the Heads of Departments; } \\
\text { - Insurance policies signed with primary companies; } \\
\text { - Access to accounts and databases is secured against internal and external } \\
\text { unauthorized access by means of authentication devices, passwords and } \\
\text { firewall; } \\
\text { When new services are launched, operational risk is identified, with the } \\
\text { indication of the monitoring and mitigation instruments; } \\
\text { - Special attention is given to the implementation of automated controls in the }\end{array}$ \\
\hline
\end{tabular}


development of IT applications which support the provision of services; Significant IT applications are reviewed before release by the Internal Auditing function and the Internal Users to assess the adequacy and quality of the automated controls;

Operational procedures, describing operating processes and related controls, are available to all relevant personnel; training programs are offered to keep an adequate level of staff expertise and risk awareness; skill profiles are kept updated c/o Resources Department to monitor the adequacy of professional competence.

\section{Contingency plans and back up facilities}

MT has developed contingency plans to cover the failure (temporary or prolonged) of key systems.

MT has outsourced its IT facilities and the daily operation of the system to SIA S.p.A, which is an IT company providing a range of services to the financial market in Italy, including payment services, trading platforms and clearing services. SIA has obtained both the quality certification (ISO9000) and a security certification (BS7799), issued by the British Standards Institute. SIA is a for-profit entity owned by the banking community.

The contingency plans developed by MT "Business Continuity and Contingency Plan" (BCCP) covers both the handling of contingencies/emergencies and the event of a major hardware failure (Disaster Recovery Plan).

The BCCP identifies different levels of contingencies such as minor contingency, emergency and disaster. Each level requires different actions to be carried out and different levels of responsibility. The classification of minor contingency and emergency type events has been established based on a risk assessment of the applications and the "survival time" for each service in case of temporary unavailability of the applications. Monthly reports are also prepared. Two formal permanent structures are responsible for managing contingency policies and emergency situations. The "Continuity Management Group" is responsible for establishing contingencies policies, identifying continuity instruments and solutions on an on-going basis and for the maintenance and updating of the BCCP. The "Emergency Management Committee," led by the Crisis Manager, is responsible for managing, monitoring and reporting emergency situations.

The BCCP includes policies and guidelines on back-up, maintenance and testing of all plants and machinery for which they are responsible (electricity, telephone and TLC lines, anti-intrusion systems, etc.)

The BCCP covers also the "Disaster Recovery Plan (DRP)" which establishes the procedures and steps to be followed in case the primary system managed by SIA is unavailable.

All procedures, data-bases and messages within the securities settlement procedures are duplicated. In case of failure of the primary system, the duplicated information may be used to ensure the smooth functioning of the system. When the failure involves the whole system, an off-site DRP is activated, ensuring the recovery of the information and restoring the operation of the system. In both cases, the DRP contemplates the utilization of a second mainframe computer where all data, processed on the primary site, are duplicated on a real-time basis. Since all 
transactions are duplicated on the two sites as they take place, in case of disruption the status of all transactions is clearly identified and no transactions are lost.

MT can resume its operations within a maximum period of four hours. The DRP defines the timing and responsibilities to activate the disaster recovery procedures and establishes guidelines to be followed for the switch-over of MT's electronic procedures and data from the primary mainframe to the off-site mainframe. It also provides guidelines for the operations processing to be carried out on SIA's premises in case of a disaster on MT's premises.

The DRPs are tested twice a year. Special contingency arrangements are in place with BI as regards the clearing and settlement platform Express II. These arrangements cover transmission procedures and databases, such as the transmission of data via alternative solutions in case of breakdown of transmission lines between $\mathrm{BI}$ and MT.

At present, intermediaries do not actively participate in DRP tests. However, one day a month SIA switches all processing (including intermediaries) from one site to the other.

\section{Protection of data communication}

Adequate measures are taken to ensure integrity, authentication, confidentiality, and non-reputability of data flows and data storage and effective firewalls are in place to protect the systems from intrusion attempts.

\section{Availability and scalability}

MT has never experienced a key system failure over the last years and resort to the DRP (failure of the primary processing site) has never occurred. The most common cause of temporary unavailability of services is application malfunctioning. Processing is on average resumed within a maximum of 3 hours. All incidents are fully documented in dedicated reports. No transactions or data have ever been lost.

\section{Audits}

External IT audit is performed by the external auditors at least once a year. An independent report on the adequacy and integrity of the IT infrastructures supporting the processing is prepared for the supervisory Authorities by the Internal Auditing function.

Furthermore, compliance with the provisions of the contract and SIA's overall reliability as an IT provider is checked by the Internal Auditing and by various MT departments.

\section{Outsourcing}

As mentioned above, MT has outsourced its IT development, management and daily operation of its system to SIA. This means that MT remains the management company of the clearing and settlement system, while it does not have any major operational tasks. In order to ensure that SIA is compliant with the same standards as if the services were provided directly by MT, the outsourcing agreement includes technical annexes which detail service standards that SIA has to guarantee in terms of securities, monitoring and control, service level, back-up and contingency 


\begin{tabular}{|c|c|}
\hline & $\begin{array}{l}\text { arrangements. MT carries out real time monitoring of SIA's compliance with the } \\
\text { agreed performance. In addition, regular meetings are held on a monthly basis } \\
\text { between MT and SIA management aimed, inter alia, at reviewing the previous } \\
\text { month's performance. Furthermore, an annual audit is carried out by the Internal } \\
\text { Auditing function of MT which checks the compliance of SIA with the agreed } \\
\text { contract, including performance, security standards, contingency procedures, etc. }\end{array}$ \\
\hline Assessment & Broadly observed \\
\hline Comments & 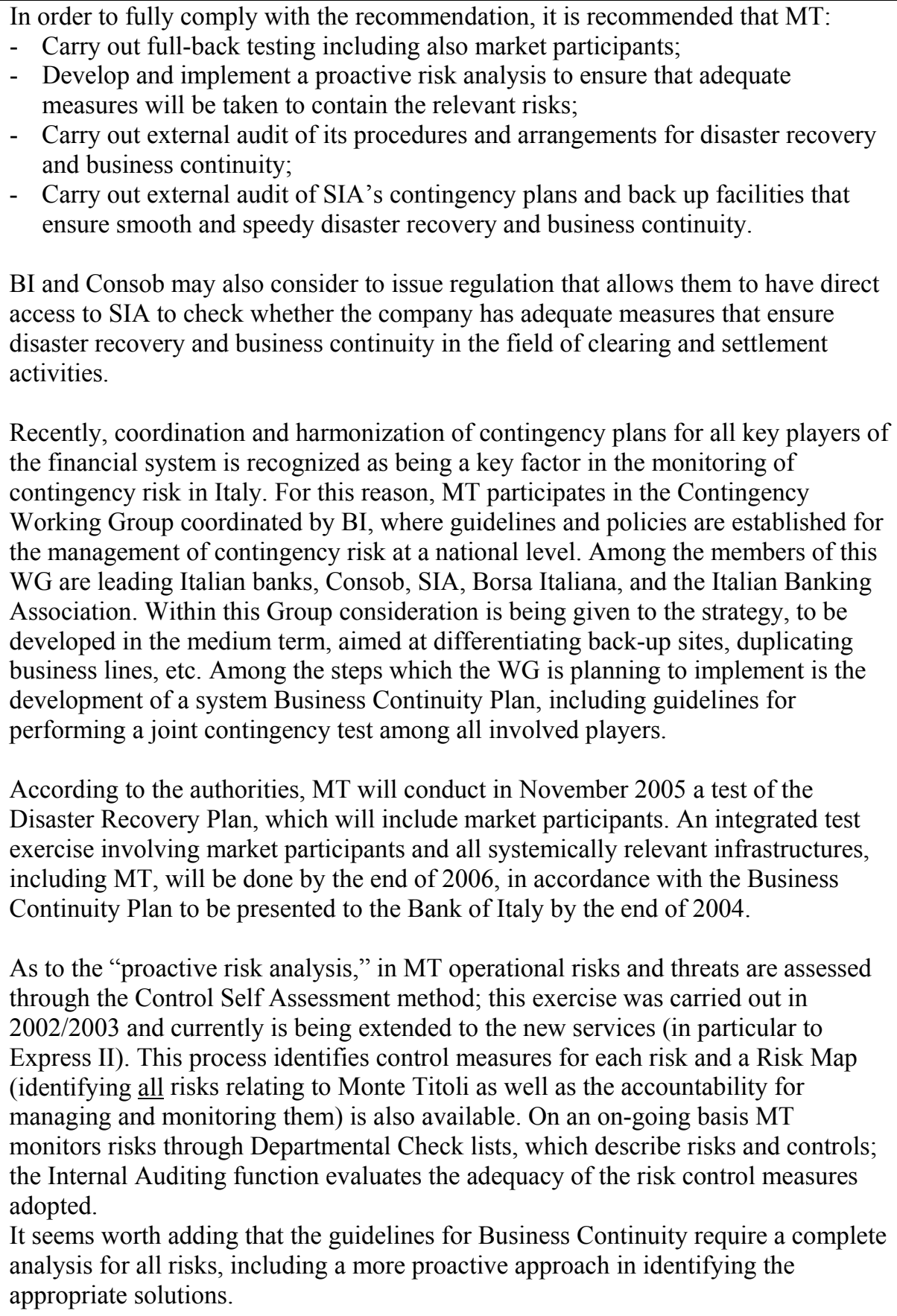 \\
\hline
\end{tabular}


MT's Board has approved an external audit for its Business Continuity Plan and procedures and for SIA's contingency plans and back-up facilities. The audit is expected to be completed by November 2005 .

With regard to the issue concerning the authorities' possibility to have direct access to SIA, the authorities have drafted guidelines addressed to the supervised companies, with a view to managing and controlling risks arising from outsourced activities, which will be shortly submitted to consultation. In particular, supervised companies would be invited to regulate the outsourcing relationships in written contracts (service level agreements - SLA) which would explicitly state that the authorities should be allowed to exercise their supervisory powers also with regard to the outsourced activities (i.e., by means of access to information, request of corrective measures). safekeeping procedures that fully protect customers' securities. It is essential that customers' securities be protected against the claims of a custodian's creditors.

\section{Institutional arrangements}

Several technical and institutional arrangements are in place in order to ensure the protection of the customers' securities. In particular, the dematerialization of the securities in custody has substantially lowered custody-related risks such as damage caused by theft, robbery, fraud, fire, loss, etc. Furthermore, MT has appropriate insurance policies to cover compensation claims. Moreover, a special guarantee reserve of Euro 8 million was set up in order to indemnify participants for any damage which they may suffer due to MT's negligence or errors in carrying out its duties.

\section{Segregation of assets}

The protection of the customers' securities is also ensured by legislative and regulatory means. For instance, the Legislative Decrees No. 58 of 24 February 1998 - TUF - and No. 213 of 24 June 1998, BI regulation of July $1^{\text {st }} 1998$ and Consob Regulation No. 11768, have specific provisions to ensure protection of customers' securities. Firstly, MT is obliged to observe the principle of complete segregation between its proprietary account and the intermediaries' and issuers' accounts. Secondly, intermediaries are obliged to have separate omnibus accounts for their customers' assets. This provision applies to the whole chain of holding - from the CSD to intermediaries and to the final investors. Participants may also open additional securities accounts ("segregated settlement accounts"), if they wish to segregate the settlement activity carried out on behalf of intermediaries or certain customers.

In the event of the insolvency of an entity holding securities on behalf of its customers (custodian), MT acts according to the provisions of the insolvency rules and according to the orders issued by a receiver/trustee that may request MT to move customer's positions to a solvent intermediary.

\section{Reconciliation procedures}

The accounting and custody procedure of MT eliminates the probability of a problem arising within MT itself. In fact, securities transfers between participants are performed through double book-entries; i.e., one debit is necessarily mirrored by one simultaneous credit of the same amount. The execution of securities transfers 
thus cannot modify the overall amount of securities handled by MT, but only its distribution among participants. When all the daily transactions activities have been processed, MT checks for each type of financial instrument that the sum of the balances of the intermediaries own and third party accounts coincides with the balance of each issue centralized in MT.

According to the Consob Regulation No. 11768 (Art. 42 and 43), custodians have to reconcile their securities accounts on a daily basis by means of the relevant IT application. Moreover, on a daily basis, MT sends intermediaries the opening and closing balance with an indication of any quantities of financial instruments that are not freely transferable and any transfers made during the day where these have not already been notified. Within one day of the date of registration, intermediaries must check for each type of financial instrument that the balance of their own account held at MT coincides with the balance of the account they keep and that the balance of the account of their customers' holdings at MT coincides with the sum of the balances of the customer accounts they keep.

The balance of the securities accounts are subject to external audits (semi-annual). Moreover, on a sample basis, tracers are sent by the external auditors to issuers and intermediaries asking for their confirmation of the securities balances kept at MT. Replies are received directly by the external auditors.

\section{Supervision of custodians}

MT as a CSD is subject to the regulation and supervision of the BI and Consob. This issue is discussed in recommendation 18.

Custodians (either banks or investment firms) holding securities on behalf of their customers are subject to rigorous regulations and supervision by Consob and BI. In particular, they are subject to specific rules on safekeeping and protection of customer's assets. They are also subject to external audits, performed according to the Italian regulatory provisions and the Accounting Principles issued by the Italian Certified Public Accountants Association.

\begin{tabular}{|l|l}
\hline Assessment & Ob \\
\hline Comments & \\
\hline Recommendation $\mathbf{1 3}$ & Gov \\
\hline
\end{tabular}

\section{Observed}

Governance arrangements for CSDs and CCPs should be designed to fulfill public interest requirements and to promote the objectives of owners and users.

\section{Governance arrangements}

Borsa Italiana Group owns 99 percent of MT. The shares of Borsa Italiana S.p.A. are held mainly by banks and financial intermediaries. It is a private for-profit company subject to the provisions contained in the Italian Civil Code (implementing the relevant European Directives on company law) on corporate governance (including on the role of the managers, of the shareholders and on the duties of the internal auditors). Moreover, as management company for regulated markets, Borsa Italiana is subject to the provisions contained in the Consolidated Law and to Consob's supervision. Pursuant to Art. 61(5) of the Consolidated Law the Minister for Economy and Finance sets out the integrity requirements that shareholders must fulfill. Acquisitions and disposals of shareholdings in market management companies must be notified in advance to Consob. 
Finance, persons performing administrative, managerial or control functions must fulfill integrity and experience requirements. Consob can disqualify the said persons for non-compliance with experience and integrity requirements.

For both entities the Articles of Association establish the basic principles regarding the Board and the Board's functioning. The updated Issuer Register is sent to the Chamber of Commerce after the Shareholders' Meeting has taken place. The Powers of Attorney are filed with the Chamber of Commerce.

Similar to other companies incorporated in Italy, the corporate bodies of MT are the Shareholder's Meeting, the Board of Directors and the Board of Statutory Auditors. The Board of Directors is appointed by the shareholders' general meeting every three years. It is currently composed, for both companies, of nine members, one of whom is an Independent Director. Board of Directors' members remain in office for three years - unless the Shareholders' Meeting that proceeds with the nomination establishes a shorter period - and they may be re-elected. The responsibilities of the Board are established by the Italian Civil Code, which implies that all members of the Board are jointly liable for damages toward the company. Some responsibilities are delegated to the Chairman, the Deputy Chairman the CEO and the General Manager. The Board of Directors can delegate its powers to designated management; the Meeting's Minutes are deposed for extract in the public register.

MT does publish their own financial results separately as well as they are aggregated in the balance sheet of Borsa Italiana.

The Statutory Auditors assist in the Board's meetings. The Board of Statutory Auditors is presently composed of three auditors and two substitute Statutory Auditors.

For both companies major decisions (modifications of the Operating rules, launch of new services, budgets, etc) are taken by the Board of Directors following proposals of the Chief Executive Officer (CEO). Supervisory Authorities are kept informed of these decisions according to the modalities set forth in the supervisory instructions. The CEO of MT is responsible for strategic issues and internal controls: the General Manager is responsible for the proper functioning of the company and the system's operation.

\section{Publication of relevant information}

Comprehensive information on MT, the ownership, boards and management structure, Articles of Association, the Annual Report, is available on the Web site of respective entity.

\section{Public interest}

MT acts within a regulatory framework that aims at fostering and guaranteeing the users' interests as well as the financial system's stability.

Art. 3 and 7 of the Clearing and Settlement Regulations state that the settlement system's operator must ensure the "orderly, transparent and continuous functioning of the system, the settlement risks' containment, levels of efficiency comparable with international best practices." Art. 82.2 of the TUF establishes that the supervisory authorities have the responsibility to ensure that the CSD's rules are suitable to guarantee the custody system's "transparency, the orderly performance 
of services and the protection of investors."

Furthermore, meetings with BI and Consob take place on regular basis aimed at discussing key issues related to the operation of the CSD and the settlement system.

\section{Users' interest}

MT maintains close working relationships with professional Association such as the Italian Banking Association (ABI), the Italian Issuers' organization (Assonime), and the Italian Investment Firms' Association (Assosim), etc.

With regard to Express II, a specific user group, composed of representatives from MT, ABI, Assosim, BI, Consob, CC\&G, leading Italian banks and regulated markets, has been established to serve as a forum ("Express User Group"). Periodic meeting are held to discuss issues, such as users' problems and system enhancements.

MT carries out consultation with users on a regular basis. Participants are also invited to share the analysis and development stages of new projects and participate in tests and validations before new applications become operational. Information about major decisions (new regulations, services, projects, changes in pricing, etc.) is provided in writing and sent to all participants in advance of their effective date.

\section{Management incentives}

The achievement of the managers (by area of responsibility) is monitored and measured by senior management. The skills of personnel are kept updated through a number of training initiatives.

Assessment

Comments

\section{Observed}

MT's governance structure was altered when their legal status changed from independent entity into fully owned subsidiary by Borsa Italiana. MT is owned directly by the entity which is managing the market place. In some countries, the restructuring of the securities market infrastructure has resulted in different shape, where separate subsidiaries for trading, clearing and settlement, respectively, are owned by a holding company. This model ensures a higher degree of neutrality between different segments of the group. Second, 7 of 9 board members of MT are managers from Borsa Italiana. This may lead to a conflict of interest, as these managers may have difficulty to separate between the objectives of the trading platform which they represent and the specific objectives of MT to serve its own customers, including those who are not members of the trading platform. In this context, all the interviewed market participants' representatives pointed out that their possibility to influence MT, except for some technical features, has become limited since MT became a part of Borsa Italiana.

Due to the unique position of MT in the Italian financial market, (i.e., de facto monopoly in settlement and custody activities), and in order to reduce any concern among MT users with regard to the objectives of the respective company, it would be advisable to increase the number of independent directors at the Board of MT.

According to the authorities, the increase of the number of independent directors at the Board of MT was discussed with the holding company Borsa Italiana; the latter agreed to do so when the existing Boards expire in the Spring 2006. 
participation that permit fair and open access.

Description Access Criteria

The access criteria to MT are strictly governed by the regulatory framework referred to in Recommendation 1 on Legal framework. Market participants receive a copy of the rules and procedures when they sign the model agreement with the two companies, respectively. Information about new regulations is immediately given to all participants through specific means of communications.

The authorities' regulations and MT's rules are available, in Italian and English on the respective Web sites, and updated on a regular basis.

Participant in MT can have access to the CSD function, the settlement system or both functionalities. Participants are subject to the same rules and requirements within the category they belong to.

The criteria of MT permit fair and open access to all financial intermediaries. In particular, participants from the EEA are subject to the same conditions as Italian entities. In case of foreign CSD, MT requires a legal opinion from an external legal adviser about the applicable terms regarding, inter alia, the applicant's capacity to execute, the applicable law in case of conflict of laws issues and whether foreign CSDs are bound by the provisions of MT's Terms and Conditions. Furthermore, an agreement between BI and Consob and the relevant competent foreign authorities is necessary. Such an agreement aims at ensuring an appropriate exchange of information among the competent national authorities and at guaranteeing reciprocity.

Capital requirements vary according to the type of clearing member. General clearing member, that are allowed to clear for non-clearing members are required to fulfill higher capital requirements also scaled on the number of non clearing members they clear for.

\section{Exit criteria}

Arrangements to terminate membership are described in the MT Services Manuals and are publicly disclosed. Withdrawal procedures from the contract of participation in the settlement services and related activities are available on MT Web site www.montetitoli.it. Participants can terminate their membership at any time giving prior notice to MT (three months for custody services and 30 days for clearing and settlement services). During this period, participants have to ensure the execution of all pending contractual obligations. MT terminates a participant's membership in the System if it is cancelled from:

- the national register of investment firms;

- $\quad$ the national register of banks;

- the national stockbrokers' list;

- the list of financial institutions established by the Banking Act of 1 September 1993.

Furthermore, MT can terminate a participant's membership if the participant loses the requisites which allowed it to adhere to the system (requirements are included in the legal and contractual provisions) and if the participant does not fulfill its contractual obligations vis-à-vis the system. 


\begin{tabular}{|c|c|}
\hline Assessment & Observed \\
\hline Comments & $\begin{array}{l}\text { Compared to other major European settlement systems, foreign access to MT on a } \\
\text { remote basis has so far been limited. As an explanation, two main reasons have been } \\
\text { put forward: } \\
\text { - Foreign participants need to have a fiscal presence in Italy. } \\
\text { - Access to intraday central bank credit is restricted. } \\
\text { For cost-efficient reason foreign participants prefer to appoint local custodians to } \\
\text { clear their transactions rather than having direct access to MT. } \\
\text { According to the authorities, both factors are out of the Monte Titoli's control. The } \\
\text { fiscal requirements are set by the Ministry of Economy and Finance and access to } \\
\text { intraday central bank credit (i.e., to the Eurosystem's credit) is disciplined by the } \\
\text { "General documentation on Eurosystem monetary policy instruments and } \\
\text { procedures." No other relevant reasons appear that could encourage the appointment } \\
\text { of local custodians by remote market participants. }\end{array}$ \\
\hline Recommendation 15 & $\begin{array}{l}\text { While maintaining safe and secure operations, securities settlement systems should } \\
\text { be cost-effective in meeting the requirements of users. }\end{array}$ \\
\hline Description & $\begin{array}{l}\text { Procedures to control cost } \\
\text { MT has in place procedures aimed at identifying the costs corresponding to each } \\
\text { service. Operating costs are systematically checked on a monthly basis. Every month } \\
\text { management is informed of cost trends and of the differences between foreseen and } \\
\text { effective amounts. Almost all services offered by MT are completely automated. } \\
\text { Therefore, fixed costs (in terms of staff expenses and investment costs) represent the } \\
\text { highest part of operating costs and are quite easy to control. } \\
\text { Procedures to review pricing levels } \\
\text { MT does not benchmark its costs against those of other CSDs, as it is difficult to } \\
\text { have information on the different costs of other CSDs. In addition, it is important to } \\
\text { keep in mind that MT is a private for-profit entity and the interference by public } \\
\text { authorities with regard to benchmarking its cost is, of course, restricted in Italy due } \\
\text { to the freedom of decision making within private sector's companies. } \\
\text { However, MT compares its price and service levels against those of other European } \\
\text { CSDs. It reviews its pricing policy each year aimed at: } \\
\text { - covering costs; } \\
\text { - ensuring the efficient use of services; } \\
\text { - offering competitive and cost-effective services; } \\
\text { - achieving a reasonable ROE. } \\
\text { Procedure to review service levels } \\
\text { MT provides clearing and settlement services through an IT provider company - } \\
\text { SIA. The service levels are subject to modification due to identified changes in a } \\
\text { certain parameters (volumes) or when new services need to be introduced. } \\
\text { Furthermore, MT periodically convenes User Groups to discuss its level of service } \\
\text { level. Market participants and public authorities are involved in the consultation } \\
\text { process. In addition, MT uses the information gathered through its customer support } \\
\text { (help desk) to improve its service levels. }\end{array}$ \\
\hline
\end{tabular}




\begin{tabular}{|c|c|}
\hline & $\begin{array}{l}\text { Dedicated business and technical customer support departments provide support and } \\
\text { problem resolution related to service issues, such as answering questions about how } \\
\text { to use the applications, and establishing and testing electronic access connections. } \\
\text { Operational reliability and capacity levels } \\
\text { Operational reliability and possible malfunctioning are systematically checked on a } \\
\text { monthly basis with the IT provider. MT has put in place penalty mechanisms to } \\
\text { control and react to its IT provider in case of noncompliance with contractual } \\
\text { provisions. For further details on this issue, refer to recommendation } 11 \text {. }\end{array}$ \\
\hline Assessment & Observed \\
\hline \multicolumn{2}{|l|}{ Comments } \\
\hline Recommendation 16 & $\begin{array}{l}\text { Securities settlement systems should use or accommodate the relevant international } \\
\text { communication procedures and standards in order to facilitate efficient settlement of } \\
\text { cross-border transactions. }\end{array}$ \\
\hline Description & $\begin{array}{l}\text { Communication procedures and standards } \\
\text { The network communication between MT and the participants is based on the } \\
\text { following communication channels: } \\
-\quad \text { - RNI (the National Interbank Network); } \\
-\quad \text { MT-X, the platform based on internet technology. } \\
\text { - Swift network } \\
\text { Although, SWIFT messages are offered to MT's participants, domestic participants } \\
\text { prefer to use RNI, while SWIFT messages are always used when communicating } \\
\text { with foreign entities (intermediaries, central counterparties and central securities } \\
\text { depositories) for cross-border transactions. In order to handle simultaneously } \\
\text { different communication protocols MT has developed procedures aimed at easily } \\
\text { converting RNI messages to SWIFT ones and vice versa. The RNI, which is based } \\
\text { on a proprietary format, allows the uses of international standard message types and } \\
\text { procedures for the securities identification process, but counterparty identification is } \\
\text { not based on internationally recognized identifiers. } \\
\text { As regards Express II, the integrated clearing \& settlement platform and the RRG } \\
\text { matching and routing services that support it, is available through the new } \\
\text { SWIFTNet technology. } \\
\text { Moreover, MT has developed MT-X, an Internet Communication System. MT-X is } \\
\text { a Web-based platform for knowledge and document management. It also allows } \\
\text { intermediaries to send and receive all types of messages presently available through } \\
\text { the other communication channels (RNI and SWIFT). MT-X can also be used by } \\
\text { MT and participants as a back-up channel in case of unavailability of either RNI or } \\
\text { SWIFT. }\end{array}$ \\
\hline Assessment & Observed \\
\hline Comments & \\
\hline Recommendation 17 & $\begin{array}{l}\text { CSDs and CCPs should provide market participants with sufficient information for } \\
\text { them to identify and evaluate accurately the risks and costs associated with using the }\end{array}$ \\
\hline
\end{tabular}




\begin{tabular}{|c|c|}
\hline & CSD or CCP services. \\
\hline Description & $\begin{array}{l}\text { Disclosure of information } \\
\text { Laws, regulations, systems' rules, and fees are part of the contractual agreements } \\
\text { which are to be signed by participants. In particular, participants' rights, obligations } \\
\text { and costs are defined in these documents, which are also available, on the Web site } \\
\text { of the companies (in Italian and English). } \\
\text { MT's risks and steps taken to mitigate them are described in the Disclosure } \\
\text { Framework and in the Business Continuity and Contingency Plan, also available on } \\
\text { the Web site in Italian and English. MT also publishes the answers to the Global } \\
\text { Custodians questionnaire. } \\
\text { Disclosure Framework } \\
\text { The Disclosure Framework is prepared by senior staff, according to their } \\
\text { responsibilities. It is reviewed and approved by senior management before issuance; } \\
\text { the document is periodically reviewed and updated by the responsible managers. } \\
\text { The same process is followed for the Global Custodians questionnaire. } \\
\text { The CPSS/IOSCO Disclosure Framework has been completed and disclosed. The } \\
\text { last update version was made available in December } 2003 \text {. }\end{array}$ \\
\hline Assessment & Observed \\
\hline Comments & $\begin{array}{l}\text { As discussed with market participant, the pricing structure of MT is not entirely } \\
\text { clear. In particular, the prices of some specific transactions such as the settlement of } \\
\text { failed trade, reporting and reconciliation services are not separated in the invoices } \\
\text { received by market participants. } \\
\text { According to the authorities, the pricing structure of MT is clearly defined and } \\
\text { publicly available on the MT Web site. In particular the pricing structure identifies } \\
\text { the following transaction fees: a) settlement fee (night settlement cycle); b) } \\
\text { settlement failures fee (day light settlement cycle); c) gross settlement cycle fee; d) } \\
\text { RRG services fee. Such a distinction is provided also in the MT's invoices; } \\
\text { intermediaries are consequently able to verify the amount of the individual items } \\
\text { recorded on invoices and match it with their internal records. A detailed table of } \\
\text { correspondence between the items of the price list and invoices is available to } \\
\text { participants. }\end{array}$ \\
\hline Recommendation 18 & $\begin{array}{l}\text { Securities settlement systems should be subject to transparent and effective } \\
\text { regulation and oversight. Central banks and securities regulators should cooperate } \\
\text { with each other and with other relevant authorities. }\end{array}$ \\
\hline Description & $\begin{array}{l}\text { Regulation and oversight framework } \\
\text { The central securities depository (CSD) and securities settlement system (SSS) are } \\
\text { subject to adequate legislative, regulatory and supervisory framework, refer to } \\
\text { Recommendation } 1 \text {. } \\
\text { Pursuant to Supervisory Instructions issued jointly by BI and Consob, a report is } \\
\text { issued annually by the Board of Directors of the respective company and sent to } \\
\text { both authorities. The document: } \\
\text { describes the Company's corporate Governance and the organizational structure }\end{array}$ \\
\hline
\end{tabular}


supporting the services;

describes the structure of the system of internal controls and evaluates its adequacy and efficiency;

describes the measures adopted to ensure the secure and efficient operation of the services provided;

describes and assesses the risk management policies and risk mitigation measures; reports on the results of the internal and external audits and verifications.

Furthermore, MT's business rules and conditions are decided by the respective Board of Directors and submitted to BI and Consob for approval. They check the service rules to ensure transparency, the orderly performance of services and the protection of investors and may require them to amend their service rules with a view to eliminating any problems found. They also require MT to periodically communicate data, information, records and to forward specific documentation.

Moreover, audits and examinations are performed by three bodies: the Internal Auditing, an independent function reporting to the CEOs of each company, the External Auditors and the Statutory Auditors. External audits are performed according to the Italian regulatory provisions and the Accounting Principles issued by the Italian Certified Public Accountants Association. Their scope includes the companies' financial statements as well as the adequacy and sufficiency of the internal controls structure. The Statutory auditors' activities are regulated by law: they perform periodic checks and examinations to ensure that the companies are meeting both the regulatory legal and fiscal requirements as well as the objectives established by the Board of Directors. The Statutory Auditors participate to the meetings of the Board of Directors or respective company.

Responsibility of regulators and overseers

The tasks and the role of $\mathrm{BI}$ and Consob with respect to securities clearing and settlement activities are clearly defined in the legislative texts and respective rules and regulations, which are published on the Internet both in Italian and in English. All the authorities' regulations are published on the Official Journal of Repubblica Italiana. In particular, the TUF distinguishes between CSD and SSS. The authority that has the lead responsible for the regulation and supervision of CSD is Consob, while BI is the lead regulator and supervisor of SSS. Consequently, relevant regulations for the CSD are issued by Consob in agreement with the $\mathrm{BI}$, while the regulations for the SSS are issued by BI in agreement with Consob. In particular, BI is responsible for the containment of systemic risk and the soundness of securities clearing and settlement systems. Consob is responsible for the transparency, protection of investors and proper conduct. Both Consob and BI have joint responsibility for the regularity of transactions carried out on regulated markets. Their organization structures are based on experienced staff, proper resources and funding to carry out effectively their respective regulatory functions.

\section{Cooperation between regulators and overseers}

The cooperation between BI and Consob is defined in the TUF provisions which require that $\mathrm{BI}$ and Consob: a) share their information, and b) co-ordinate between each other to best performing their respective tasks. This holds both for financial intermediaries and for market infrastructures where there is a joint competence. To this end they cannot invoke official secrecy in their mutual relations

Consob and the BI, pursuant to the abovementioned law, can cooperate and share 
information with foreign regulators for the purpose of facilitating their respective functions. Confidentiality and proper protection of the information must be ensured by the requesting authority.

Moreover, Consob and the BI may also exchange information with:

administrative and judicial authorities in connection with winding-up or bankruptcy procedures;

bodies responsible for the clearing and settlement of market transactions, for the purpose of ensuring the regular operation of the systems they manage;

market operators, for the purpose of ensuring the regular operation of the markets they manage.

The cooperation between Consob and BI takes place along the organizational line of both authorities. In particular, two meetings per year take place between the Governor of BI and the Chairman of Consob. Senior managers meet on a regular basis and working groups are established to deal with specific issue including drafting joint regulations and instructions.

$\mathrm{BI}$ and Consob cooperate with other relevant authorities at the European level such as the ESCB/CESR Committee and at global level as the CPSS/IOSCO working group on securities clearing and settlement systems.

\begin{tabular}{|c|c|}
\hline Assessment & Observed \\
\hline Comments & \\
\hline Recommendation 19 & $\begin{array}{l}\text { CSDs that establish links to settle cross-border trades should design and operate } \\
\text { such links to reduce effectively the risks associated with cross-border settlements. }\end{array}$ \\
\hline Description & $\begin{array}{l}\text { Links in operation } \\
\text { MT has established links to the following CSDs: } \\
\text { - Clearstream Banking Frankfurt, Germany } \\
\text { - Euroclear France, France } \\
\text { - OeKB, Austria } \\
\text { - Iberclear, Spain } \\
\text { - Euroclear Bank, Belgium } \\
\text { - Euroclear Netherlands, The Netherlands } \\
\text { - Clearstream Banking Luxemburg, Luxemburg } \\
\text { - SIS, Switzerland } \\
\text { - DTC, United States } \\
\text { Mode of settlement } \\
\text { So far, all the links established by MT are free of payment (FOP). The links are } \\
\text { used to transfer securities without the corresponding cash amount. The links are } \\
\text { mainly used for the transfers of collateral for monetary policy operations. } \\
\text { Risk analysis } \\
\text { MT has carried out risk analysis covering, inter alia, the legal soundness, the } \\
\text { protection of customer's holding, finality and operational reliability. The securities } \\
\text { accounting procedure verifies on a transaction by transaction basis the } \\
\text { correspondence between the internal evidence of the omnibus account held with the } \\
\text { foreign CSD and the balances of MT's particinants accounts. }\end{array}$ \\
\hline
\end{tabular}




\begin{tabular}{|l|l|}
\hline & $\begin{array}{l}\text { Since the links are FOP no analysis is needed with regard to DVP mechanism or the } \\
\text { failure of the participants. } \\
\text { Credit extension } \\
\text { There is no cash leg in the FOP links. In addition, MT does not provide credit. }\end{array}$ \\
\hline Assessment & Observed \\
\hline Comments & \\
\hline
\end{tabular}


Table 1. Summary of Observance of CPSS/IOSCO Recommendations

\begin{tabular}{|l|l|}
\hline Reference recomm & \multicolumn{1}{c|}{ Recommendations } \\
\hline Observed $1,2,3,4,5,6,7,8,9,10,12,13,14,15,16,17,18,19$ \\
\hline Broadly Observed 11 \\
\hline Partly observed & \\
\hline Non-observed & \\
\hline
\end{tabular}

Table 2. Actions to Improve Observance of the Recommendations

\begin{tabular}{|c|c|}
\hline $\begin{array}{c}\text { Reference } \\
\text { recommendation }\end{array}$ & Recommended action \\
\hline Recommendation 5 & $\begin{array}{l}\text { In order to reduce the legal uncertainty, MT should accelerate the work in developing } \\
\text { standardized legal documentation for the securities lending facility. }\end{array}$ \\
\hline Recommendation 9 & $\begin{array}{l}\text { The level of end-of-day failure remains slightly higher in terms of value of transactions } \\
\text { (about } 1.2 \% \text { ), while it is low in terms of volume (about } 0.35 \text { ). In order to reduce settlement } \\
\text { failures to insignificant level in terms of value, MT may consider to strengthen its stress } \\
\text { testing by analyzing various scenarios for the uncovered cash positions and further fine- } \\
\text { tuning adjustment of the optimization algorithm. }\end{array}$ \\
\hline Recommendation 11 & $\begin{array}{l}\text { In order to fully comply with the recommendation, it is recommended that MT: } \\
\text { Carry out full-back testing including also market participants; } \\
\text { Develop and implement a proactive risk analysis methodology to ensure that adequate } \\
\text { measures will be taken to contain the relevant risks; } \\
\text { Carry out external audit of its procedures and arrangements for disaster recovery and } \\
\text { business continuity; } \\
\text { Carry out external audit of SIA's contingency plans and back up facilities that ensure } \\
\text { smooth and speedy disaster recovery and business continuity. } \\
\text { BI and Consob may also consider to issue regulation that allows them to have direct access } \\
\text { to SIA to check whether the company has adequate measures that ensure disaster recovery } \\
\text { and business continuity in the field of clearing and settlement activities. }\end{array}$ \\
\hline Recommendation 13 & $\begin{array}{l}\text { Due to the unique position of MT in the Italian financial market, (i.e., de facto monopoly in } \\
\text { settlement and custody activities), and in order to reduce any concern among MT users with } \\
\text { regard to the objectives of the respective company, it would be advisable to increase the } \\
\text { number of independent directors at the Board of MT. }\end{array}$ \\
\hline
\end{tabular}

\section{Authorities' response:}

The Italian authorities (IA hereinafter - Banca d'Italia and Consob) contend that Recommendation 11 has been fully observed. In this respect, the authorities underline that:

- $\quad$ as required, Monte Titoli (MT) will conduct on December, $3^{\text {rd }} 2005$ a Disaster Recovery Plan (DRP) test, with an extensive involvement of participants and other market infrastructures; the results of the DRP test will be timely disclosed to the IMF staff as soon as available; 
- the MT risk analysis framework has been fully successful in "proactively" preventing the materialization of any kind of risks even in the delicate phases of the implementation of services and procedures very complex and totally new;

- as required, an external audit on the MT Business Continuity Plan and Procedures and on SIA's contingency plans and back-up facilities is being carried out and is expected to be completed by the end of the year; if requested, the IA would inform the IMF staff of the main findings of the audit report;

- the IA have already drafted guidelines addressed to the supervised entities with a view to managing and controlling risks arising from outsourced activities; these guidelines, inter alia, would explicitly state that the authorities should be allowed to exercise their supervisory powers also with regard to the outsourced activities. 